\title{
Evaluating the Adoption and Use of Internet-based Marketing Information Systems to Improve Marketing Intelligence (The Case of Tourism SMEs in Jordan)
}

\author{
Professor Dr. Basheer AL-allak \\ Department of Marketing and Entrepreneur Development \\ College Of Business Management and Accounting \\ Universiti Tenaga Nasional, Sultan Haj Ahmad Shah Campus \\ 26700 Bandar Muadzam Shah, Pahang, Malaysia \\ E-mail: alalak_2003@yahoo.com
}

\begin{abstract}
The study investigates the nature of marketing information systems within tourism small- and medium- sized enterprises and focuses on the usefulness of the Internet for external information gathering. The findings indicate that tourism SMEs make use of informal marketing information systems which concentrate on immediate operating data at the expense of external data, and that the Internet has not yet been recognized as an important source for marketing intelligence despite having the benefits of providing much of the necessary data for good decision- making more quickly and at a lower cost compared with many other sources. The study identifies obstacles and challenges that reduce the uptake of the Internet, and suggests practical solutions.
\end{abstract}

Keywords: MkIs, Internet, ICT, Tourism, Marketing intelligence

\section{Introduction}

The importance of marketing information is particularly evident as the economy continues to emphasise services as a primary source of value. Services are heavily information dependent. Information is rapidly becoming a service in its own right. Indeed, the revolution in information technology (IT) has propelled "information" to the position of the most critical factor in wealth creation (Braun and Holick, 2006; Arlt, 2006). However, it is the advent of the Internet, and especially the browser-based World Wide Web, which has ignited a revolution in Marketing Information Systems (MkISs) (Harmon, 2003). Furthermore, in today's knowledge-based society, development of good information can provide a company with a jump on its competitors, provided that it is able to develop, deploy, and manage powerful new marketing information systems that are capable of converting knowledge rapidly into customer value (Choi, et al. 2007). This can only be achieved when the marketing function is developed and scaled up on "Internet time" with best-of-class decision support solutions for sales force automation, marketing, intelligence, marketing research, logistics, communications, and product development.

An important part of this evaluation entails the existence of a marketing information system that enables managers to carry out their analysis, planning, implementation and control responsibilities in highly competitive markets, and to be able to achieve competitive advantage. The key to competitive advantage depends on the firm's ability to utilize this comprehensive, flexible, and highly integrated system in such a way as to convert knowledge into stakeholders' relationships, reduced time to market and lower costs.

Therefore, marketing information system design is important since the quality of a MkIS has been shown to affect the effectiveness of decision-making (Kimery and Amirkhalkha, 2007). It has also been shown that the use of IT within MkISs has become a key factor in an organization's achievement of competitive advantage (Choi and Morrison, 2006; Han and Mills, 2006; Anandkumar, 2008).

Simply put a MkIS, in electronic form or otherwise, is a system that is designed to provide an organized flow of information to enable and support the marketing activities of an organization. Moreover, as Kotler and Keller's (2007) definition says, a MkIS is more than a system of data collection or a set of information technologies. It is rather a continuing and interacting structure of people, equipment and procedures to gather, sort, analyse, evaluate, and distribute pertinent, timely and accurate information for use by marketing decision makers to improve their marketing planning, implementation and control. A MkIS has four components: the internal recording system, the marketing research system, the marketing intelligence system and marketing models. Internal reports include orders received, inventory records and sales invoices. Marketing research takes the form 
of purposeful studies either ad hoc or continuous. By contrast, marketing intelligence is less specific in its purposes, is chiefly carried out in an informal manner and by managers themselves rather than by professional marketing researchers $(\mathrm{Li}, 1997)$. For the purpose of this study, marketing intelligence is defined as information obtained from external sources that can be used for the proper identification of problems, changes and opportunities in the external marketing environment (Talvinen, 1994).

The system can be formal or informal. A formal information system defines very clearly the work-flow system, communication flow-down and the authority. The information flows in terms of policies, goals, strategies, rules and regulations from the top level management to the bottom level of management. The information also flows from the bottom level management to the top level in terms of feedback, results of work done, etc. In contrast, the informal information system is employee-based and cater to their development and solve work related problems in a much less organized manner (Gourvennec, 2005).

It is worth mentioning that a MkIS has to be designed to meet the way in which managers tend to work. Research suggest that a manager continually addresses a large variety of tasks and is able to spend relatively brief periods on each of these. Given the nature of the work, managers tend to rely upon information that is timely and verbal (because this can be assimilated quickly), even if this is likely to be less accurate than more formal and complex information systems (Samaleen, 2005; Samadi, 2005).

\section{Review of Literature}

Research show that the impact of information and communication technology (ICT) on MkIS's effectiveness has been drastic. In essence, the effective use of ICT has leveraged the quality of decision making process resulting in the enhancement of market monitoring, strategy development and implementation, and functional integration (Harmon, 2003; Ho and Lee, 2006). Others (e.g. Al-Taee, 2006; Gourvennec, 2005) argue that the effective use of ICT can improve not only the performance and functionality of a MkIS but can also improve firm level productivity and innovation by allowing for more cost effective and fluid communication with all stakeholders, improving logistics, overcoming distance, helping firms understand their competitive positioning and enhancing transparency. However, successful ICT deployment requires innovative management to constantly review developments and adopt suitable technological solutions in order to maximize organizational competitiveness (Buhalis and O'Connor, 2005). A good start would be the design of an ICT-enabled MkIS (AL-ALAK, 2008).

Numerous research also show that the tourism and hospitality industry has been transformed by ICT. The Internet has dramatically changed the way in which consumers plan and buy their holidays and other tourism products. It has also affected how tourism and hospitality providers promote and sell their products and services (UNCTAD, 2002). Furthermore, using Internet-based MkISs enables tourism and hospitality businesses themselves to formulate effective strategies that address and meet the real needs and wants of a large number of consumers at a relatively low cost, and to interact with them as well as with other tourism producers and distributors (UNCTAD, 2005). Indeed, the tourism and hospitality industry is one of the industries to adapt quickly to ICT and the e-marketing practice. The transition has been swift and comprehensive to such an extent that the structure of the industry is changing (Gratzer and Winiwarter, 2003), and the competitiveness of the marketplace is altered (Bulhalis, 2003).

Werthner and Klein (1999) demonstrate how the World Wide Web has profoundly changed the production, distribution and consumption of touristic products, and conclude that ICT is probably the strongest driving force for changes within the tourism and hospitality industry, and the major contributor to the achievement of competitive advantage. Dodds, et al. (2010) show that the adoption of ICT has leveraged the effectiveness and efficiency of the tourism industry, thus enabling it to achieve sustainable competitive advantage.

Internet-based and ICT supportive MkISs have transformed the tourism industry into a truly digital economy (Buhalis and Spada, 2000), and that e-tourism has evolved from a technology trend to a mainstream tourism business reality, creating opportunities as well as challenges for both practitioners and researchers in the area (Papathanassis and Buhalis, 2007).

In many emerging economies, the tourism industry is dominated by private sector, comprising largely of small and medium enterprises (SMEs). These entities find opportunity to expand their businesses through online channels with very low entry barriers and reach large markets that would never be accessible to them offline (Hormozi, et al. 1998). Although SMEs do not have an established place in the Internet economy yet, some of them are making rapid strides to become an integral part of e-business and marketing environment in the tourism industry (Anandkumar, 2008). Yi-Ling, et al. (2010) argue that for tourism SMEs, ICT has been a blessing since it has created a business environment where creativity flourishes and cost reductions become possible, not to mention the role of ICT in changing the organizational structure of these SMEs from the traditional type to a flat 
one, making them better equipped to serve their customers efficiently and effectively. However, the situation regarding SMEs involved in the tourism and hospitality sector in the majority of Arab countries, and some other developing countries is quite different. These SMEs still lack mechanisms to establish formal Internet-based or ICT-backed MkISs that would enable them to communicate effectively with their clientele and stakeholders (Samadi, 2005; Al-Taee, 2006).

In Egypt, Syria and Lebanon, which are major tourism destinations in the Arab region, the Internet is used mainly as a marketing tool, mostly for promotional activities by the SMEs (El Said and Hone, 2005), whereas in Jordan and Tunis, the Internet is merely used for ad hoc information gathering (Al-ALAK, 2008). This is done despite the fact that the Internet is capable of providing these SMEs with direct customer, stakeholder contact, a new world wide distribution channel, and success and dominance in their tourism and hospitality sectors. Tourism SMEs in Turkey, a major tourist destination in the Middle East, were investigated to determine whether they utilize MkISs of any form. The study revealed that only $26 \%$ of these enterprises had Internet access, and only $11 \%$ of those with access incorporated the Internet into a meaningful MkIS (Ozgener and Iraz, 2006). The researchers attribute this 'harsh reality' to tourism SMEs having short-term business horizons and often limited knowledge of the business environment, being primarily family businesses whose resources and channels of maintaining business relations and their ability to create necessary surplus for expansion are limited.

Researchers highlight the importance of the small firm in the hospitality and tourism sector and show that there are sufficient grounds and justifications for examining such organizations as a separate analytical category from both small firms in general and other, larger tourism and hospitality firms (Martin, 2004; Al-Taee, 2006). The current research focus on SMEs in the attractions and accommodation subsectors in Jordan is attributed to the fact that over $95 \%$ of all firms in the tourism and hospitality sector in Jordan are classified as small and medium-sized (Jordan Department of Statistic, 2007). Also, the accommodation and attractions sub sectors are the largest sector in the tourism industry of Jordan (Jordan Ministry of Tourism and Antiquities, 2007). The contribution of this sector in the Jordanian Domestic Product (GDP) in 2007 stands at $18.6 \%, 10.3 \%$ of which comes from accommodation (Central Bank of Jordan, 2007). It is interesting to note that tourist contribution in export increased from $40.9 \%$ in 1994 to $74 \%$ in 2007 , giving an indication of the importance of this sector for the economy of Jordan (Jordan Ministry of Tourism and Antiquities, 2007).

A review of relevant literature (pertaining to tourism SMEs and the use, benefits and challenges of Internet-based MkISs in the tourism industry) points to a paucity of research into the Internet marketing practices of tourism SMEs and prompted this research that will go someway towards contributing to knowledge in this area. The paper discusses the practical implications of the findings for the tourism SMEs.

According to a number of studies (e.g. Sigala, 2003 a, b; Schart et al 2004; Taylor, 2004; Zafiropoulos and Vrana, 2006; Sausser and Ariga, 2006; Zeithaml and Britner, 2003; Li, 1997) the service sector tends to be less marketing orientated with less use of external information than the manufacturing sector, and more functionally orientated than marketing orientated, and as such, the majority of service organizations do not possess formal, comprehensive and systematic MkIS. This is especially the case with the majority of SMEs in the service sector (Samaleen, 2005).

Tourism SMEs have also been found to have less reliance on systematic MkISs, whether Internet-based or otherwise. Research show that tourism SMEs in the majority of Arab countries utilize mainly internal data at the expense of external information on which to base long-term decisions (Al-ALAK, 2008, Mustafa, 2007; Safadi, 2005). ICT adoption and Internet use by the majority of Arab tourism SMEs is characterized by oversimplification, irregularity, and strong resistance (Muniri, 2007). A survey of 293 small companies in Egypt by Hawari (2007) confirms that tourism SMEs are not fully exploiting latest information technologies to create competitive advantage, and that the collection of environmental data by these SMEs is rarely done in a systematic or proper manner. The finings show that surveyed SMEs generated internal data, customer data and some competitor information mainly from sales call reports, and the utilization of ICT was either poor or non-existent.

Tourism SMEs in other parts of the world seem to have similar characteristics and patterns of behavior. A study by Anandkumar (2008) shows that tourism SMEs are slow in adopting ICT in their businesses due to resource constraints. Buhalis (1996) and Hull and Milne (2001) identify a number of challenges that reduce the uptake of ICT by tourism SMEs worldwide, including: a lack of training and capital, limited understanding of the potential of technology, and a lack of clear business strategies. Nodder, et al. (2004) attribute the reluctance of tourism SMEs to adopt comprehensive Internet-based MkISs and other technologies to small business owners' intimidation by the "hidden costs" of ICT adoption, such as training and upgrading software, as well as the 
precautions about time commitments and the problems of relying on external expertise. Lin, et al. (2009) demonstrate that tourism SMEs are sometimes reluctant to invest heavily in ICT and internet-based MkISs due to the belief that online transactions might affect travel purchase intention in a negative way. However, Law (2009) refutes such beliefs, pointing out that tourists in general go for speedy and less costly tourism services, and that ICT is highly favored by such tourists. Law suggests that tourism SMEs conduct survey research among tourists to see whether or not tourists favor ICT-oriented tourism service transactions (online transactions).

Other organizations in the tourism industry seem to face different kinds of problems and challenges in this domain. According to Choi, et al. (2007) destination marketing organizations (DMOs) are facing intriguing challenges to provide quality information online in an era of information overload. Insufficient knowledge of tourist's online information preferences and search behavior has hindered them from effective information management. To remedy part of this challenge, it is recommended that a sound Internet-based MkIS be constructed in such a way as to incorporate decision support solutions for customer relationship management, market research, marketing communications, logistics, and product development (Harmon, 2003). Law (2009) shows that customer relationship management in the tourism industry will be highly enhanced and leveraged in an effective way when based on (1) continuous market research, (2) sound marketing intelligence, (3) integrated marketing information system, (4) a good blend of tourism marketing mix, and (5) commitment to customer-orientation strategy. There have also been vigorous discussions about the DMOs' evolving role in customer service and contact through closer relationships with private sectors and integrated information systems (Buhalis, 2000; Gretzel et al., 2000; Scott et al., 2000; Ritchie, 2005). It is suggested that the adoption of ICT by tourism businesses, especially SMEs, will have a revolutionary impact on the marketing discipline, transforming MkISs from being merely decision-making aids, into major sources of competitive advantage, as these ICT-supported MkISs will increasingly involve the customer in the value creation process and work to more effectively align the enterprise and its supply chain on rapidly changing market opportunities (Papathanassi and Buhalis, 2007; AL-ALAK, 2008; Hull and Milne, 2001). A study by Buhalis and O'Connor (2005) states that e-tourism will be focused on consumer centric technologies to ensure that the new sophisticated and experienced consumers are served. As such, the researchers recommend that agile strategies be formulated at both strategic and tactical management levels to develop the 'infostructure' for tourism organizations to manage their internal functions, their relationships with partners and their interactions with all stakeholders including consumers. The study concludes that "...only those organizations that appreciate the opportunities which ICTs bring and manage their resources successfully will be able to enhance their innovation and competitiveness in the future" (Buhalis and O'Connor, 2005, P. 16). Xiang, et al. (2009) argue that the adoption of internet-based MkISs in particular, and ICT in general plays a leading role in enhancing the image of the tourism organization among its customers. They show that customers who perceive the organization as ICT-oriented tend to talk about it favorably, thus spreading positive word-of-mouth communications about it.

AL-ALAK and Al-Taee (2006) and Baloalu and Peckan (2006) argue that there is no logical excuse for tourism and hospitality SMEs for not utilizing Internet-based MkISs to seek marketing intelligence information, monitoring the business environment properly, and conducting customer-oriented research, as these functions can be carried out at minimal costs and at unprecedented speed and effectiveness. Arlt (2006) suggests that in order to overcome some of the problems identified with Internet use, perseverance and practice are necessary from the business manager. The main obstacle therefore might be in convincing managers that this effort will eventually pay dividends. The importance of marketing intelligence (external data) as a vital component of any successful MkIS has been emphasized in previous research (Hawari, 2007; Martin, 2004; AL-ALAK, 2008; Nodder et al., 2004; Muniri, 2007). Research also show that SMEs need a MkIS that is not resource intensive but will still provide the internal and external information needed to make good marketing decisions (Wood, 2001). The advent of the Internet and the benefits of ICT have made this possible provided that other obstacles already outlined by Buhalis $(2000,1996)$, and Papathanassis and Buhalis (2007), and Nodder at al. (2004) are overcome. In today's business world where the internet has become a reality and an effective business facilitator at almost minimal cost, SMEs in the tourism industry should spare no moment in utilizing its tremendous potentials for the advancement of their business. It is argued by Chhabra (2009) that tourism SMEs will reap the fruits of the internet when they incorporate the internet with other marketing systems and strategies, where the power of the internet will be truly tremendous.

From the introduction and literature discussed above it can be concluded that a MkIS is desirable and perhaps necessary in order to compete successfully and ensure a competitive advantage for SMEs, especially in the tourism and hospitality sector. However, it may not need to be formally structured or resource intensive. A more important factor than the structure appears to be the extent of external information gathered compared with 
internal data. Tourism, as an information-intensive sector, has significantly benefited from ICTs. Yet, tourism SMEs, especially in the Arab region, have been less reluctant to incorporate these technologies into their MkISs, or to design proper MkISs capable of benefiting from ICTs, especially the Internet. The Internet is undoubtedly a rich source of external information, and ICTs have proven to create competitive advantages, especially for tourism SMEs. In order for these enterprises to take advantage of these technologies they need to overcome any initial problems, persevere and to integrate the information found with internal data within a formal or informal MkIS.

\section{The Study}

\subsection{Scope of the Study}

The aims of this study are to identify the current form of MkIS used within SMEs in the tourism and hospitality sector in Jordan and to measure the awareness within this sector of the information available via the Internet. Also, to determine if and how these firms use the Internet for obtaining marketing intelligence (external information data), and to gather the opinion of the information users within the target group on the usefulness of the Internet for marketing intelligence gathering and to discover what problems have been encountered or anticipated with Internet use for marketing intelligence. Only independently run businesses were surveyed, e.g. excluding government owned tourist attractions and five-star chain hotels. The objective was to screen out those who may have access to the marketing information system of a larger organization.

Based on the introduction and the review of literature, specific research hypotheses were advanced and tested in order to realize the aims of the current study. These hypotheses were statistically tested to determine whether there was a difference between the attractions and accommodation subsectors in the tourism and hospitality sector in Jordan, and to see whether there existed positive relationships between a number of independent variables, namely: the size of the firm, its age, characteristics, Internet access planned, year Internet accessed, and the dependent variable namely: external information gathering practices and frequency.

\subsection{Methodological Approach and Research Design}

The primary research method used to meet the objectives of the current research was largely a quantitative postal survey. This method was chosen after consideration of general methodological issues (positivist versus phenomenological issues) and previous research undertaken in similar areas and sectors (Castaneda et al., 2007; Law et al., 2004; Huang and Law, 2003). As the current research does not seek to gather data on the service encounter itself but on the use of a marketing tool, survey research is found to be more appropriate compared to qualitative research (Buhalis, 2003; Chen and Yen, 2004; AL-ALAK, 2008). The survey instrument was pretested and implemented during the period 26.4.2008-17.8.2009. Petra, Wadi Rum, Umm Qais, Aqaba, Dead Sea (as tourist attractions) and Greater Amman Area and Madaba (as accommodation) were chosen owing to the number and variety of suitable SMEs in the sector of interest situated within this region and its accessibility. A detailed questionnaire containing twenty one questions was formulated to achieve the research objectives. The survey instrument was pre-tested and implemented through a carefully chosen group of research assistants who volunteered to administer the questionnaire. Almost $96 \%$ of all tourist destinations in Jordan are located in the selected region. Three hundred and fifty companies were selected so that with an expected response rate of $30 \%$ the survey would result in at least 105 completed questionnaires. This response rate is typical of similar postal survey within the field, such as (Arlt, 2005; Baloglu and Peckan, 2006; Costas, et al; 2005; Wood, 2001; Thomas et al., 1997). This would allow for a variety of statistical techniques to be used for analysis of the data and for some separate analysis of the two subgroups if major differences become apparent.

As the current research was interested in both the total population and possible comparisons between the two strata, a compromise was made between an even split (suitable for comparison) and proportional split (suitable for population total) [Hair et al. 2003]. This resulted in the final sample size of 150 companies from the attractions subsector and 200 from the accommodation subsector. Stratified random sampling was used to select the required number of each type of company from the sampling frame. Several statistical techniques including Chi-square, Man-Whitney Test, Pearson's coefficient of correlation were used in this study.

\section{Results of the Data Collected}

Out of the total of three hundred and fifty (150) questionnaires posted to the selected proportional sample of SMEs, ninety-six usable responses were received (see Table 1). Average responding company was small and well established in business. Respondents had worked for the business for 5-8 years on average and should have a good knowledge of the business and its operating environment. Summary of current Internet usage within the sample 
suggests that 51\% have Internet access and 49\% do not. Eighty-six percent of all respondents were either owners, managing directors or general managers (see Table 2).(Insert table 1 and table 2 here)

As far as external information gathering frequency is concerned, current marketing information systems primarily focus on existing customers. This is undertaken more regularly than in the other information areas. The second key area is local and national competitors. The area monitored least frequently or not at all is international competitors and the international economy (see Table 3).(Insert table 3 here)

Organizations with Internet access appeared to be more aware of the general sources and uses of marketing intelligence than those without Internet access. This is illustrated in details in Table 4. The Internet as a source of information is also highlighted in Table 4 to give some indication of the awareness and hence use of this medium. Further understanding of the level of awareness is gained from analyzing the extent of Internet access within the sample and from the quantitative data provided (see Table 2).(Insert table 4 here)

Table 5 provides further detail on the $51 \%$ currently accessing the Internet. Most organizations (69\%) have gained access to the Internet only recently [this year (2008) and a year ago (2007)] and have only one terminal connected (75.5\% of Internet user response), therefore the number of employees who access it is not surprisingly small.(Insert table 5 here)

When asked about the information that respondents mainly collected through the Internet, it was revealed that the Internet was found to be of most use for gathering information on local, national and international competitors and the international economy $(82 \%)$. The other external information areas (customers and the national economy) scored the minimum possible, suggesting that the Internet was of little use in these areas (see Table 6).(Insert table 6 here)

Table 7 shows that the main benefit of the Internet as an information source for Internet users was seen as 'valuable supplementary source of information', which scored higher than 'ease and speed of access', 'up-to-date' and 'value for money'. Non-users envisage fewer problems than the users actually experience. Non-users foresee disadvantages as being largely cost based, whereas experience has led users to state lack of trained employees and technical expertise as the main problems.(Insert table 7 here)

Data generated by the questionnaire also revealed that the Internet is mainly used for information gathering (41\% of Internet-user respondents), followed by information publishing (26.5\%), and promotion (22.4\%). It is surprising that only $8 \%$ of respondents said that they used the Internet for customer service, $2.1 \%$ for selling products and services. None of the respondents used the Internet for purchasing purposes (see Table 8).(Insert table 8 here)

These findings are similar to those of Hawari (2007), where 33\% of small companies were found to have access (see Figure 1). Also, Hawari found that $81 \%$ of non-Internet users were intending to access it within 5 years. This almost corresponds with the current survey where $65 \%$ of non-users were intending to gain it within the next 3 years. The remaining 35\% had no plans to gain access.(Insert figure 1 here)

\subsection{Testing of Hypotheses}

A number of statistical techniques such as Chi-squared test, Man Whitney test, and Pearson's coefficient of correlation, were used to test the study hypotheses. Chi-squared analysis and Man Witney test were used to determine whether the two subsectors in the current study vary very little in areas of importance to this research. It was concluded that it would not be beneficial to conduct a separate analysis of each subsector (see Table 9 and Table 10).(Insert table 9 and table 10 here)

Pearson's coefficient of correlation was used as a measure of the strength of linear relationship between two variables (i.e. company's characteristics such as company age, company size, current Internet access... and external information gathering) [Hair et al. 2003].

The results show that a high positive correlation exists between company size and external information gathering frequency. It can be concluded therefore that the larger the company the more external information is gathered (see Table 11).(Insert table 11 here)

The relationship between business age, year Internet accessed, and external information gathering frequency was statistically tested. It was found that the relationship was negative, therefore, the most recently established companies that are relatively new to the Internet gather external data more frequently (see Table 12).(Insert table 12 here)

The relationships between (number of terminals, current Internet access, Internet access planned and number of employees using the Internet) and external information gathering frequency were also tested. A very low positive 
correlation exists between external information gathering and current Internet access and Internet access planned. In this case, there is no positive relationship between the number of employees using the Internet and external information gathering. Also, number of terminals has very low negative correlation with external information gathering frequency (see Table 13).(Insert table 13 here)

To determine whether there exists a positive relationship between (company size, business age) and Internet access, a Chi squared sig. was used. Results show that the size and age of the sample organizations do not appear to determine whether or not they connect to the Internet (see table 14).(Insert table 14 here)

\section{Conclusions and Recommendations}

The average responding company in the tourism sector in Jordan is small and well established in business. 51\% of the target group has Internet access, and the majority of SMEs surveyed are run by the owners themselves, with assistance from general managers.

The current form of marketing information systems used within tourism SMEs is based largely on internal data supplemented by customer survey and informal investigations and local and national competitors. No evidence of the existence of marketing orientated information systems is found. Indeed, the sector is more operationally focused than marketing orientated as manifested by the sector's reliance on personal contacts and personal experience and knowledge rather than hard facts and quantitative data. Marketing research is hardly conducted and subjective and qualitative judgments prevail. However, experience and knowledge also has value, but this value does not seem to be enhanced with more quantitative methods. The majority of MkISs are poorly designed, lacking flexibility, comprehensiveness and the ability to create an organized and timely flow of information required by marketing decision makers.

The gathering of information from wider external sources is limited. There is a state of 'in-balance' between external data to internal data gathering activity. The majority of tourism SMEs surveyed approach marketing intelligence gathering in a less deliberate fashion, not training their sales force, after-sales personnel and district/area managers to take cognizance of competitors' actions, customer complaints and requests and distributor problems. Information technology is not greatly utilized to aid information gathering, analysis and management.

Although $51 \%$ of tourism SMEs are online, their use of the Internet for marketing intelligence is limited. The Internet is only regarded as a supplementary tool alongside other sources, which seem to carry more importance than the Internet as a source of external information. This may suggest the existence of a number of obstacles that make tourism SMEs less inclined to integrate or utilize this technology in their businesses, including: limited understanding or appreciation of the potential of technology, 'hidden costs' of technology adoption, such as training, external expertise and upgrading software, or a lack of clear business strategies. Such conclusions correspond with a number of studies by renowned scholars such as: Buhalis (1996, 2003, 2007), Hull and Milne (2001), and Nedder et al., (2004).

Furthermore, despite all resource constraints encountered by tourism SMEs surveyed, accessing the Internet is viewed favorably even by non-Internet users. Indeed, the majority of such constraints can be alleviated by the efficient use of the Internet, provided that its power is integrated into a well designed MkIS.

The state of 'in-balance' between external data to internal data gathering activity can be improved by making data more accessible. This can be achieved through the use of a shared MkIS for certain data types (e.g. internal continuous data, internal and ad hoc data and environmental scanning) and the use of the Internet as the main source of other external data. The Internet also will be the method of communication with the shared MkIS and contact network. Smaller tourism organizations in Jordan would benefit from the Internet facilities of the Ministry of Tourism and Antiquities, the Tourism Promotion Board, the Association of Tourism and Travel Agencies, the Ministry of Information and Communication Technology, and the Hotel Association of Jordan. These measures will reduce some of the cost and time intensive elements of the MkIs. It would not be difficult or costly to collect and analyse internal data from sources such as: internal record system, existing customer information, and financial data using IT, and this would enable the easier integration of the external and internal data. It also must be ensured that the less formal, less regular, qualitative information gained from sources such as: personal experience knowledge, sector contact network, printed media, trade associations, T.V., conferences, symposiums etc, is incorporated within the system because this information is important for marketing decision making. Furthermore, environmental scanning will be made easier, less costly and less time consuming. In this way, scanning will enable smaller and resource poor firms to act upon rather than react to opportunities and threats. The focus is on the long-term perspective allowing SMEs to be in the position to plan ahead. This will 
also enable tourism SMEs to formulate clear business strategies, gain a better understanding of the potential of technology.

Tourism SMEs in Jordan are called upon to take full advantage of the REACH initiative which offers all SMEs technical and managerial assistance at nominal cost, especially in the fields of training, IT infrastructure, human resource management, and other types of expertise.

The initiative, which was launched 5 years ago by King Abdulla II of Jordan aims at encouraging SMEs to adopt ICT in businesses, and thus overcoming the challenges that reduce the uptake of ICT by SMEs. Managers should therefore think seriously of adopting ICT, as this technology enables them to achieve the competitive advantage required by the tourism sector in order to grow and prosper. Tourism SMEs in Jordan should make a calculated start by developing a better MkIS if resources could be improved or information gathered more easily and cheaply. The alleviation of the resource problems encountered by tourism SMEs in Jordan can be achieved through the efficient use of the Internet as an information source and through the development of Internet communication with a network of companies and organizations. The sharing of information through regular communication and key web-site scanning should enable SMEs to gain some of the benefits afforded to larger resource-rich organizations, provided that the power of the Internet is integrated into a sound MkIS.

This is deemed vital considering the fact that tourism SMEs in competing neighboring countries (e.g. Egypt, Israel and Lebanon) are relying more and more on Internet-based MkISs, and as such are competing for more and more tourists and guests at the expense of Jordanian tourism and hospitality SMEs.

\subsection{Limitations and Directions for Future Research}

Additional research should be conducted to investigate how the creative use of information technology can give tourism and hospitality SMEs in Jordan a sustainable competitive advantage, and how to generate ideas for using information technology in innovative ways, and tools that can help. It may also be interesting to examine how e-commerce technologies "up the shakes" and give SMEs even more opportunities. In this respect, there is a need for further research to provide significant new insights into the development and implementation of e-business strategies that will lead tourism and hospitality SMEs in Jordan to achieve competitive advantage. The success of application of e-business strategy to chain hotels (5+ star hotels) depends on the value added of e-business to the hotel industry. Currently, many 5+ star hotels (which were excluded from our study) are looking at e-business to protect their assets and to secure customer's loyalty, and to be successful in today's competitive environment. It would be interesting to see whether this kind of customer-centric e-business system (which utilizes Internet technology) can also be applied to tourism and hospitality SMEs in Jordan.

Furthermore, the continuing assimilation of Information Technology (IT) into tourism marketing practice is an issue of our time, and as such it deserves special consideration by researchers. As IT assimilation continues and becomes a norm of business and marketing operations, these issues will resolve themselves. The future for marketing will have an embedded IT element. Marketers are currently struggling to embrace IT, though in time the expertise will develop as a core requirement of marketing. Marketers need to have a broad range of IT skills and knowledge of a range of IT systems particularly now as the applications develop. Academics need to study current and potential impacts and advise on future developments.

Future research needs to be done to examine other regions comparable to Jordan that can be used to benchmark MkIS techniques and implications for Jordan and other areas. Furthermore, the research does not cover all attraction sites and accommodation in Jordan. Instead; concentration is made on tourist attractions within the so-called Tourism Golden Triangle, and on accommodation located in the capital Amman. One would probably expect more comprehensive results had all regions in Jordan were covered by the research. Consequently, future studies should focus on other tourism and hospitality enterprises, small, medium and large, and both government and privately owned tourist attractions and five-star chain hotels.

It should also be stated that the study was conducted at a given point in time as it examined Jordanian owners / directors' knowledge of the Jordanian tourism market. Knowledge is, of course, subject to change. The study is also subject to all limitations recognized in the collection of data by postal questionnaires.

And finally the current study deals with only one Arab country - Jordan. As is the case in many other developing countries, published reliable and comprehensive statistics are scare in Jordan, and these statistics may be inaccurate due to inadequacy of information. 


\section{References}

Akour, I, Alshare, K, Miller, K and Dwairi, M. (2006). An Exploratory Analysis of Culture, Perceived Ease of Use, Perceived Usefulness, and Internet Acceptance: The Case of Jordan. Journal of Internet Commerce, 5 (3), 83-106.

AL-ALAK, B. (2008). The Reality of Competitive Disadvantages and Lost Opportunities for Tourism SMEs in Selected Arab Countries. Yarmouk University Journal, 2(1): 111-1113.

Al-Alak, B., and Al-Taie, H. (2006). Perceived Quality of services provided by hotels in Jordan among foreign guests. Dirasat Journal for Business Research, 4(6), 210-226.

Al-Taie, H. (2006). Internet Marketing of Tourism Services. Proceedings of the $7^{\text {th }}$ conference of E-business, Al-Zaytoonah University of Jordan, April, 288-301.

Anandkumar, S. (2008). E-marketing for Small and Medium Tourism Enterprises in Mauritius and Andaman Islands. AIMS International, 2 (2), 93-114.

Arlt, W. (2005). A virtual Huanying, Selamat Datang and Herzlich Willkommen! The Internet as a Cross Cultural Promotional Tool for Tourism. In C. Haven-Tang and E. Jones (Eds.), Tourism SMEs, Service and Destination Competitiveness: International Perspectives (325-336). Wallingford: CAB International.

Arlt, W. (2006). Not very Willkommen: The Internet as a Marketing Tool for Attracting German Speaking Tourists to Non-European Destinations. Journal of Information Technology and Tourism, 8, 227-238.

Arnold, C. (2004). Not done net. Marketing News, April, 17.

Baloglu, S., and Peckan, Y. (2006). The Web Design and Internet Site Marketing Practices of Upscale and Luxury Hotels in Turkey. Journal of Tourism Management, 27(1), 171-176.

Braun, P and Hollick, M. (2006). Tourism Skills Delivery: Sharing Tourism Knowledge Online. Education and Training, 48(8/9), 77-89

Buhalis, D and O'Conner, P. (2005). Information Communication Technology Revolutionizing Tourism. Tourism Recreation Research, 30(3), 7-16.

Buhalis, D and Spada, A. (2000). Destination Management Systems, Criteria for Success- an Exploratory Research. Information Technology and Tourism, 3, 41-58.

Buhalis, D. (1996). Enhancing the Competitiveness of Small and Medium Sized Tourism Enterprises at the Destination Level by Using Information Technology. Electronic Markets, 6(1), 1-6.

Buhalis, D. (2000). Tourism in an era of information technology. In: Tourism in the Twenty-First Century, Faulkner B, Moscardo G, Laws E(Eds.). Continuum (pp 163-180): New York.

Buhalis, D. (2003). E-Tourism: Information Technology for Strategic Tourism Management. London: Financial Times / Prentice-Hall.

Castaneda, J, Frias, D and Rodriguez, M. (2007). The Impact of the Internet on Destination Satisfaction. Internet Research, 17 (4), 97-129.

Central Bank of Jordan, Statistics Department, Annual Report, January, 2008, 30-39.

Chaffey, D., R., Johnston, K., \& Ellis Chadwick, F. (2000). Internet Marketing: Strategy, implementation and practice. London: Prentice-Hall and Financial Times.

Chen, K and Yen, D. (2004). Improving the Quality of Online Presence Through Interactivity. Journal of Information Management, 42, 217-226.

Chhabra, D. (2009). Proposing a sustainable marketing framework for heritage tourism. Journal of sustainable tourism, 17(3):303-320.

Choi, S and Morrison, A. (2006). Website Effectiveness for Bricks and Mortar Travel Retailers. Anatolia: An International Journal of Tourism and Hospitality Research, 16(1), 63-78.

Choi, S, Xinran, Y and Oleary, J. (2007). What Does the Consumer Want from a DMO Website? A Study of US and Canadian Tourists' Perspectives. Int. J. Tourism Res. 9, 59-72.

Collin, S. (2000). E-Marketing: Working the Web. The U.K: John Wiley and Sons, Ltd. 
Costas, et al. (2005). An Evaluation of the Performance of Hotel Websites Using the Managers' Views About Online Information Services. Working Paper [Online] Available: http://csrc.lse.ac.uk/asp/aspecis/20050010.pdf.retrieved23/10/07

Dodds, R., Graci, S., and Holmes, M. (2010). Does the tourist care? Journal of sustainable Toursim, 18 (2):207-222.

El Said, G, and Hone, K. (2005). Culture and E-commerce: An exploration of the Perceptions and Attitudes of Egyptian Internet Users. Journal of Computing and Information Technology, 13(2), 107-122.

Featherman, M and Wells, M. (2004). The Intangibility of E-services: Effects on Artificiality, Perceived Risk, and Adoption. Proceedings of the $37^{\text {th }}$ Hawaii International Conference on System Sciences, IEEE.

Gourvennec, Y. (2005). From complex customers to the M.O.I.S, reproduced in Dirasat Journal for Business Research. Jordan University, 3(4), 111-114.

Gratzer, M and Winiwarter, W. (2003). The Role of the Internet in the SME hotel sector in Austria. In G. Goos, J. Hartmanis and J. Van Leeuwen (Eds.), Web and Communication Technologies and Internet-related Issues (pp 28-39). Springer: Berlin.

Gretzel, U, Yuan, Y and Fesenmaier, D. (2000). Preparing for the new economy: advertising strategies and change in destination marketing. Journal of Travel Research, 39(2), 146-156.

Hair, J., Babin, B, Money, A and Samouel, P. (2003). Essentials of Business Research Methods. London: John Wiley and Sons, Inc.

Han, H and Mills, J. (2006). Zero Acquaintance Benchmarking at Travel Destination Websites: What is the First Impression that National Tourism Organizations try to make? International Journal of Tourism Research, 8(6), 405-430.

Harmon, R. (2003). Marketing Information Systems. Encyclopedia of Information Systems, 3; 138-139.

Hawari, S. (2007). Information Technology Utilization by Small Hospitality and Tourism Companies in Egypt. Ein Shams University. Journal of Administrative Science Research, 11(3), 27-31.

Ho, C and Lee Y. (2006). The Development of an E-travel Service Quality Scale. Tourism Management, 28, 1434-1449.

Honomichl, J. (2004). Honomichl 50, Special Section. Marketing News, June 15, H1-H55.

Hormozi, A, Harding, W and Base, U. (1998). Is the Internet Feasible and Profitable for Small Businesses? SAM Advanced Management Journal, 63(3), 20-26.

Huang, W., Le, T and Li, X. (2006). Categorizing web features and functions to evaluate commercial websites. An Assessment Framework and an Empirical Investigation of Australian Companies. Industrial Management and Data Systems Journal, 106(4), 523-539.

Huang, X and Law, R. (2003). Modeling and Comparing Internet Marketing: A study of Mainland China and Hong Kong based hotel websites. Journal of Information and Communication Technologies in Tourism. New York: Springer-Verlag Wien, 173-182.

Hull, J and Milne, S. (2001). From Nets to the "Net": Marketing Tourism on Quebec's Lower North Shore. In: Baerenholdt. N.E. an Aarsaether J.O (Eds.) Coping Strategies in the North (pp 89-93). Copenhagen: Nordic Council of Ministers, 89-93.

Jang, S. (2004). The Past, Present, and Future Research of Online Information Search. Journal of Travel and Tourism Marketing, 17(2/3), 41-47.

Jordan Department of Statistics. Tourism Trends and Indicators. Statistics Department. Annual Report, December, 2007, 111-117.

Jordan Ministry of Tourism and Antiquities, Research Department, Assessment Breiefs, November, 2007, 14-15.

Jordan Royal Scientific Society. (2006). A critique of the Jordan Tourism Sector. Special report / JTC, Amman, 6-9.

Kimery, K., and Amirkhalkhali, S. (2007). National Culture and Diffusion of Electronic Commerce: Preliminary Results From Japan and the U.S.A. EABR (Business) and ETLC (Teaching) Conference Proceedings, Venice, Italy.

Kotler, P, and Armstrong, G. (2006). Principles of Marketing. New Jersey: Pearson Education. 
Kotler, P, and Keller, K. (2007). Marketing Management. New Jersey: Pearson Education.

Law R; Leung K and Wong, R. (2004). The Impact of the Internet on Travel Agencies. International Journal of Contemporary Hospitality Management, 16(2), 100-107.

Law, R. (2009). E-Business and Hospitality Management. 18 (8): 741-742.

Law, R. (2009). Internet and Tourism. Journal of Travel and Tourism Marketing. 26 (7): 747-749.

Law, R., Law, A., \& Wai, E. (2001). The impact of the Internet on travel agencies in Hong Kong. Journal of Travel and Tourism Marketing, 11(2/3), 105-126.

Legoherel, P, Fischer-Lokou. J., and Gueguen, N. (2003). Selling Tourism on the Internet: Analysis of the Balance of Power Between Seller and Consumer During Information Exchange and Negotiation. Journal of Tourism and Leisure Marketing, 9(13), 49-63.

Lewis, I and Semeijn, J. (1998). The Impact of ICT on Travel Agents. Transportation Journal, 37(4), 20-26.

Li., E. (1997). Marketing Information Systems in small companies. Information Resources Management Journal, 10(1), 27-35.

Lin, P., Jones, E., \& Westwood, S. (2009). Perceived Risk and Risk-Relievers in Online Travel Purchase intentions. Journal of Hospitality Marketing Management, 18 (8):782-810.

Loch, K, Straub, D and Kamel, S. (2003). Diffusing the Internet in the Arab World: The Role of Social Norms and Technological Cultivation. IEEE Transactions of Engineering Management, 50(1), 45-63.

Lovelock, C. (2001). Services Marketing: People, technology, strategy. $4^{\text {th }}$ edition. New Jersey: Prentice-Hall.

Martin, L. (2004). E-innovation: Internet Impacts on Small UK Hospitality Firms. International Journal of Contemporary Hospitality Management, 16 (2), 82-90.

Moore, R. (2004). The Rising Tide. Change, May / June, 36, ISSOP\#3, 56-61.

Muniri, K. (2007). ICT Adoption by Tourism SMES in North Africa: Challenges, Obstacles, and Possible Remedies. Knowledge Horizon Scientific Journal, Beirut University, Beirut, Lebanon 1(3), 47-52.

Mustafa, A. (2007). Tourism SMEs and the Lack of Strategic Information Initiatives for Competitive Advantage. Dirsasat Business Journal, The University of Jordan, 6(4), 93-96.

Nodder, G; Mason, D; Ateljevic, J and Milne, S. (2004). ICT Adoption an Use in New Zealand's Small an Medium Tourism Enterprises. In: Arab Administrative Organization Journal, 14(7), 201-218.

O'Connor, J., and Galvin, E. (1997). Marketing and Information Technology. London: Pitman Publishing.

Ozgener, S an Iraz, R. (2006). Customer Relationship Management in SMEs: The Case of Turkish Tourism Industry. Tourism Management, 27, 1356-1363.

Papathanassis, A and Buhalis, D. (2007). Exploring the Information and Communication Technologies Revolution and Visioning the Future of Tourism, Travel and Hospitality Industries, $6^{\text {th }}$ e-Tourism Future Forum: ICT Revolutionizing Tourism 26-27 March 2007, Guildford, The UK. In. J. Tourism Res. 9, 385-387.

Ritchie, J and Crouch, G. (2003). The Competitive Destination: A Sustainable Tourism Perspective. Wallingford, UK.: CABI Publishing.

Safadi, W. (2005). SMEs and Environmental Scanning in Tourism Sector: Evaluating and Assessing ICT Capabilities. Ein Shams Journal of Economics \& Business, Ein Shams University, Cairo, Egypt, 16(8), 70-72.

Samadi, S., (2005). Internet-based mechanisms for SMEs in the Tourism industry. Yarmouk Research Journal, Jordan, 4(6), 32-51.

Samaleen, L. (2005). The Practice of Gathering Marketing Intelligence via Enabling Technologies. United Arab Emirates University. Journal of Scientific Research in Business, 13(7), 180-189.

Sausser, B., and Ariga, B. (2006). Teaching e-commerce WebPages evaluation and design: A pilot study using tourism destination sites. Computers and Education, 47(4), 399-413.

Scott, N, Parfitt, N and Laws, E. (2000). Destination Management: Co-operative Marketing, a case study of the Port Douglas Brand. In: Tourism in the $21^{\text {st }}$ Century, Faulkner B, Laws E, Moscardo G (Eds.). Continuum (pp 198-221): New York.

Sheehan, L and Ritchie, J. (2005). Destination Stakeholders Exploring Identities and Salience. Annals of Tourism, 32(3), 711-734.

Sheth, J., Eshgh, A., \& Krishnan, B. (2001). Internet Marketing. U.S.A.: Harcourt, Inc.

Sigala, M. (2003a). Competing in the virtual marketplace: a strategic model for developing e-commerce in the hotel industry. International Journal of Hospitality Information Technology, 3(1), 43-60. 
Sigala, M. (2003b). Developing and Benchmarking Internet Marketing Strategies in the hotel sector in Greece. Journal of Hospitality and Tourism Research, 27(4), 375-401.

Talvinen, J. (1994). Information Systems in Marketing. European Journal of Marketing, 29(1), 8-26.

Thomas, R. (1998). An Introduction to the study of small tourism and hospitality firms, In: the management of small tourism and hospitality firms, Thomas (ed). (1-16) London: Cassell.

Thomas, R., Chrch, I., Eaglen, A., Jameson, S., Lincoln, G., \& Parsons, D., (1997). The National Survey of Small Tourism and Hospitality Firms. Annual Report 1996-97. Center for the Study of Small Tourism and Hospitality Firms. Metropolitan University. The UK.

UNCTAD Report. (2002). ICT and Tourism. Retrieved October 24, 2009 [Online] Available: http://www.unctad.org/Templates/Page.asp?intItemID =3609\&lang=1\&print=1

UNCTAD Report. (2005). ICT and Tourism. Retrieved October 24, 2009 [Online] Available: http://www.uncted.org/Templetes/Page.asp?intItemID= 3611\&Lang.htm

Werthner, H and Klein, S. (1999). ICT and the Changing Landscape of Global Tourism Distribution. Electronic Markets, 9(4), 256-262.

Wober, K. (2003). Evaluation of DMO Websites through Interregional Tourism Portals: A European Cities Tourism Case Example. In: Proceedings of the10th International Conference on Information and Communication Technology in Tourism (Enter 2003) (pp 76-85). New York: Springer.

Wood, E. (2001). Marketing Information Systems in Tourism and Hospitality Small-and medium-sized enterprises. International Journal of Tourism Research, 4(3), 283-299.

Wright, M., and Ashill, N. (1998). A contingency model of Marketing Information. European Journal of Marketing, 33(1/2), 125-144.

Xiang, L., Bing, P., Zhang, L., and Smith, W. (2009). The effect of Online Information search on Image Development. Journal of Travel Research, 48 (1): 45-57.

Yi-Ling, L., and Timothly, J. (2010). The impacts of the online reservation system in London city Hotels. Journal of hospitality marketing and management, 19 (1): 82-96.

Zafiropoulos, C., and Vrana, V. (2006). A framework for the evaluation of hotel websites: The Case of Greece. Journal of Information Technology and Tourism, 8, 239-254.

Zaithaml, A., and Bitner, M. (2003). Services Marketing: integrating customer focus across the firm. $3^{\text {rd }}$ edition. U.S.A.: McGraw-Hill.

Zhou, Q, and DeSantis, R. (2005). Usability Issues in City Tourism Website design: A content Analysis. IEEE International Professional Communication Conference Proceedings, 789-796.

Table 1. Population and sample of the study

\begin{tabular}{|c|c|c|c|c|}
\hline Population & $\begin{array}{c}\text { Sample } \\
\text { (350) }\end{array}$ & $\begin{array}{c}\text { Distributed } \\
\text { Questionnaires }\end{array}$ & $\begin{array}{c}\text { Responding } \\
\text { Questionnaires }\end{array}$ & $\begin{array}{c}\text { Usable } \\
\text { Responses }\end{array}$ \\
\hline \multicolumn{5}{|l|}{ Accommodation \& Attractions subsectors } \\
\hline I-Accommodation in GAA\& Madaba 200 & $(200)$ & $(200)$ & $\begin{array}{c}(70) \\
(35 \%)\end{array}$ & $\begin{array}{c}(62) \\
(31 \%)\end{array}$ \\
\hline 1 -Acc. $2^{\text {nd }}$ class (4-stars) & 15 & 15 & 12 & 12 \\
\hline 2 -Acc. $3^{\text {rd }}$ Class (3-stars) & 40 & 40 & 13 & 12 \\
\hline 3-Acc. 4th Class (2-stars) & 35 & 35 & 10 & 08 \\
\hline $4-A c c .5^{\text {th }}$ Class (1-star) & 40 & 40 & 18 & 16 \\
\hline 5-Hotel Apartments (ABC) & 50 & 50 & 11 & 09 \\
\hline 6-Acc. In Madaba (1-2-3-4stars) 20 & 20 & 20 & 06 & 05 \\
\hline II-Attractions & $(150)$ & $(150)$ & $\begin{array}{l}(41) \\
(27 \%)\end{array}$ & $\begin{array}{c}(34) \\
(23 \%)\end{array}$ \\
\hline 1-Petra & 50 & 50 & 12 & 10 \\
\hline 2-Wadi Rum & 30 & 30 & 07 & 06 \\
\hline 3-Umm Qais & 20 & 20 & 08 & 07 \\
\hline 4-Aqaba & 40 & 40 & 13 & 10 \\
\hline 5-Dead Sea & 10 & 10 & 01 & 01 \\
\hline Total & 350 & 350 & $\begin{array}{c}111 \\
(32 \%)\end{array}$ & $\begin{array}{c}96 \\
(27 \%)\end{array}$ \\
\hline
\end{tabular}

Source: Prepared by the researcher according to collected data. 
Table 2. Characteristics of the usable sample

\begin{tabular}{|l|l|c|c|}
\hline \multicolumn{1}{|c|}{ Characteristic } & \multicolumn{1}{|c|}{ Category } & Number & Percentage \\
\hline \multirow{2}{*}{ Company size } & Less than 5 employees & 77 & 80.2 \\
& 5 to 25 employees & 19 & 19.8 \\
\hline \multirow{3}{*}{ Business age } & Less than 2 years & 46 & 11.5 \\
& 2 to 10 years & 39 & 47.9 \\
\hline \multirow{2}{*}{ Industry subsector } & more than 10 years & 34 & 35.4 \\
\hline \multirow{2}{*}{ Internet access } & Attractions & 62 & 64.6 \\
\hline \multirow{5}{*}{ Respondent's position } & Accommodation & 49 & 51 \\
& Yes & 47 & 49 \\
\hline & No & 40 & 42 \\
& Owner, Managing Director & 42 & 44 \\
\end{tabular}

Source: Prepared by the researcher according to collected data.

Table 3. Information gathering frequency

\begin{tabular}{|r|c|c|}
\hline Information Area & $\begin{array}{c}\text { Most common (modal) frequency of } \\
\text { information gathering }\end{array}$ & $\begin{array}{c}\text { Percentage stating this } \\
\text { category }\end{array}$ \\
\hline Local competitors & Ad hoc & 30 \\
\hline National competitors & Ad hoc & 28 \\
\hline International competitors & Never & 72 \\
\hline Existing customers & Daily & 31 \\
\hline Potential customers & Ad hoc & 20 \\
\hline National economy & Ad hoc & 20 \\
\hline International economy & Never & 61 \\
\hline
\end{tabular}

Table 4. Sources of information used

\begin{tabular}{|c|c|c|c|c|}
\hline \multicolumn{5}{|c|}{ Sources of information used } \\
\hline Area of interest & Non- Internet users & $(\%)$ & Internet users & $(\%)$ \\
\hline \multirow{3}{*}{ Local competitors } & Trade association & 41 & Trade association & 32 \\
\hline & Direct from competitors & 42 & Direct from competitors & 21 \\
\hline & Local paper & 4 & Internet & 10 \\
\hline \multirow{3}{*}{ National competitors } & Trade press & 62 & Trade press & 32 \\
\hline & Personal contact & 15 & Internet & 10 \\
\hline & Trade association & 7 & Trade association & 32 \\
\hline \multirow{3}{*}{ International competitors } & Newspaper/TV & 58 & Internet & 29 \\
\hline & Sales representatives & 15 & Newspapers & 38 \\
\hline & Trade press & 16 & Trade associations & 25 \\
\hline \multirow{3}{*}{ Existing customers } & Survey & 38 & Direct & 60 \\
\hline & Direct & 22 & Survey & 28 \\
\hline & Internal records & 6 & Booking records & 6 \\
\hline \multirow{3}{*}{ Potential customers } & Direct from potential customers & 26 & Trade association & 44 \\
\hline & Personal contacts & 7 & Research reports & 16 \\
\hline & Enquiries & 34 & Local/national media & 22 \\
\hline \multirow{3}{*}{ National economy } & & & National media & 58 \\
\hline & Government reports & $\begin{array}{l}21 \\
25\end{array}$ & Internet & 18 \\
\hline & & & Trade press & 22 \\
\hline \multirow{3}{*}{ International economy } & National media & 33 & Trade press & 16 \\
\hline & Trade press & 27 & National media & 40 \\
\hline & Gov. reports & 33 & Internet & 33 \\
\hline
\end{tabular}


Table 5. Duration and extent of Internet access

\begin{tabular}{|l|c|c|c|c|c|}
\hline $\begin{array}{c}\text { When access was } \\
\text { gained }\end{array}$ & $\mathbf{( \% )}$ & $\begin{array}{c}\text { Number of terminals } \\
\text { with access }\end{array}$ & $\mathbf{( \% )}$ & \multicolumn{2}{c|}{$\begin{array}{c}\text { Number of employees with } \\
\text { access (\%) }\end{array}$} \\
\hline This year & 30.6 & 1 & 75.5 & 0 & 8.2 \\
\hline 1 year ago & 38.8 & 2 & 24.5 & 1 & 28.6 \\
\hline 2 years ago & 20.4 & 3 & - & 2 & 51 \\
\hline 3 years ago & 10.2 & 4 or more & - & 3 or more & 21.2 \\
\hline
\end{tabular}

Table 6 . Information mainly collected through the Internet

\begin{tabular}{|l|c|}
\hline \multicolumn{1}{|c|}{ Area of interest } & $\begin{array}{l}\text { Internet as a source of information } \\
\text { (As a percentage of all Internet user responses) }\end{array}$ \\
\hline Local and national competitors & 20 \\
\hline International competitors & 29 \\
\hline National economy & 18 \\
\hline International economy & 33 \\
\hline
\end{tabular}

Table 7. The benefits and problems associated with the Internet as expressed by Internet and non Internet users

\begin{tabular}{|l|c|c|}
\hline \multicolumn{1}{|c|}{ Benefits } & Internet users (\%) & Non-Internet users (\%) \\
\hline Ease and speed of access & 36.7 & 31.8 \\
\hline Value for money & 4.1 & 8.6 \\
\hline Up-to-date & 14.3 & 38.3 \\
\hline Valuable supplementary source of information & 44.9 & 21.3 \\
\hline \multicolumn{2}{|c|}{ Problems } & 22.4 \\
\hline Cost of access & 10.2 & - \\
\hline Time down-loading & 10.2 & - \\
\hline Information sorting and analysis & 34.8 & 23.4 \\
\hline Lack of trained employees & 16.3 & 27.7 \\
\hline Technical expertise & 6.1 & 21.6 \\
\hline Online subscription costs & - & 3.1 \\
\hline Other & & \\
\hline
\end{tabular}

Table 8 . The purpose for which the Internet is actually used

\begin{tabular}{|l|c|}
\hline \multicolumn{1}{|c|}{ Purpose } & Respondents stating this purpose \% \\
\hline Information gathering & 41 \\
\hline Marketing research, survey, etc. & - \\
\hline Communication & - \\
\hline Customer service & 8 \\
\hline Information publishing & 26.5 \\
\hline Selling products and services & 2.1 \\
\hline Promotion & 22.4 \\
\hline Purchasing & - \\
\hline
\end{tabular}

Table 9. Chi-squared results of different industry subsectors

\begin{tabular}{|l|l|l|l|}
\hline \multicolumn{1}{|c|}{ Characteristics } & \multicolumn{1}{c|}{ Calculated Chi-squared } & \multicolumn{1}{c|}{ Critical value } & \multicolumn{1}{c|}{ Conclusion } \\
\hline Company size & Chi-squared $=35.042$ & $<\mathrm{X}^{2}(1,0.05)=3.841$ & Significant difference \\
\hline Internet access & Chi-squared $=0.042$ & $<\mathrm{X}^{2}(1,0.05)=3.841$ & No Significant difference \\
\hline Business age & Chi-squared $=21.438$ & $<\mathrm{X}^{2}(2,0.05)=5.991$ & Significant difference \\
\hline Environment dynamism & Chi-squared $=3.375$ & $<\mathrm{X}^{2}(1,0.05)=3.841$ & No Significant difference \\
\hline External information gathering & Chi-squared $=2.667$ & $<\mathrm{X}^{2}(2,0.05)=5.991$ & No Significant difference \\
\hline
\end{tabular}

Table 10. Mann-Whitney test results. The hypothesis tested is, Ho= There is no difference between the two subsectors

\begin{tabular}{|r|r|r|}
\hline Characteristics & Results & Conclusion \\
\hline Number of employees & Reject Ho & Difference between subsectors \\
\hline Business age & Reject Ho & Difference between subsectors \\
\hline Dynamic environment & Accept Ho & No Difference between subsectors \\
\hline External information gathering & Accept Ho & No Difference between subsectors \\
\hline Job of respondent & Reject Ho & Difference between subsectors \\
\hline
\end{tabular}


Table 11. Company size correlation with external information gathering

\begin{tabular}{|l|c|c|}
\hline $\begin{array}{c}\text { Variable correlated with } \\
\text { external information gathering }\end{array}$ & $\begin{array}{c}\text { Pearson's coefficient of } \\
\text { correlation }\end{array}$ & Result \\
\hline Company size & 0.511 & High positive correlation \\
\hline
\end{tabular}

Table 12. Business age, year Internet accessed correlation with external information gathering

\begin{tabular}{|l|c|c|}
\hline $\begin{array}{c}\text { Variables correlated with } \\
\text { external information gathering }\end{array}$ & $\begin{array}{c}\text { Pearson's coefficient of } \\
\text { correlation }\end{array}$ & Result \\
\hline Business age & -0.301 & Low negative correlation \\
\hline Year Internet accessed & -0.290 & Low negative correlation \\
\hline
\end{tabular}

Table 13. Correlation of external information summary data with other variables

\begin{tabular}{|l|c|c|}
\hline \multicolumn{1}{|c|}{$\begin{array}{c}\text { Variables correlated with external } \\
\text { information summary }\end{array}$} & $\begin{array}{c}\text { Pearson's coefficient of } \\
\text { correlation }\end{array}$ & Result \\
\hline Business age & -0.301 & Low negative correlation \\
\hline Year Internet accessed & -0.290 & Low negative correlation \\
\hline Number of terminals & -0.115 & Very low negative correlation \\
\hline Current Internet access & 0.112 & Very low positive correlation \\
\hline Internet access planned & 0.102 & Very low positive correlation \\
\hline Number of employees using the Internet & 0.004 & No correlation \\
\hline
\end{tabular}

Table 14. Analysis of factors affecting Internet access

\begin{tabular}{|l|l|c|c|c|}
\hline \multicolumn{2}{|c|}{ Factors } & Internet access (\%) & No Internet access (\%) & Chi-squared sig. \\
\hline \multirow{2}{*}{ Company size } & $<5$ employees & 31 & 49 & $0.101(\mathrm{DF}=1)$ \\
& $5-25$ employees & 20 & - & \multirow{2}{*}{$0.000(\mathrm{DF}=2)$} \\
\hline \multirow{3}{*}{ Business age } & $<2$ years & - & 11 & \\
& 2-10 years & 10 & - & \\
& $>10$ years & 38 &
\end{tabular}

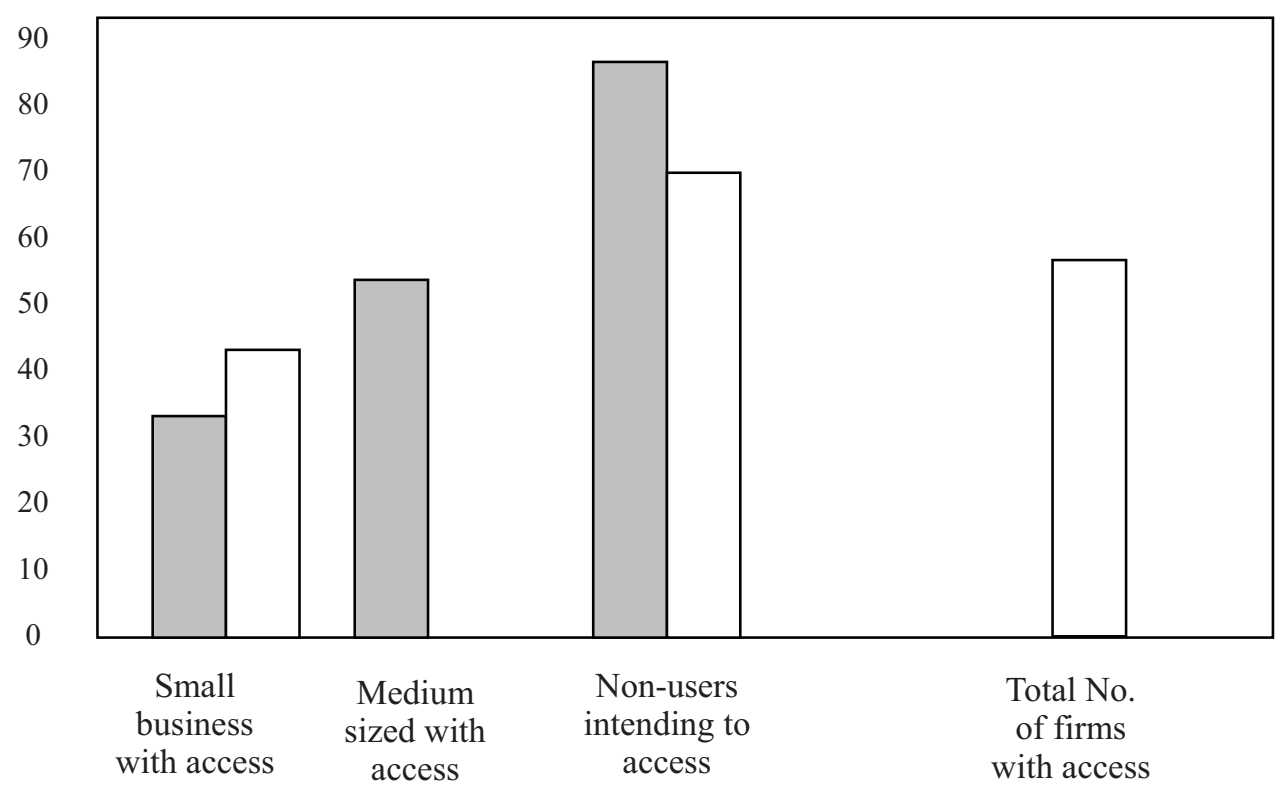

Hawari

Al-ALak

Figure 1. Internet Access-Results Comparison with Hawari (2007) 